\title{
Front Matter: Volume 8041
}

, "Front Matter: Volume 8041," Proc. SPIE 8041, Head- and Helmet-Mounted Displays XVI: Design and Applications, 804101 (13 June 2011); doi:

10.1117/12.901409 SPIE Event: SPIE Defense, Security, and Sensing, 2011, Orlando, Florida, United 


\section{PROCEEDINGS OF SPIE}

\section{Head- and Helmet-Mounted Displays XVI: Design and Applications}

Peter L. Marasco

Paul R. Havig

Editors

28 April 2011

Orlando, Florida, United States

Sponsored and Published by

SPIE

Volume 8041 
The papers included in this volume were part of the technical conference cited on the cover and title page. Papers were selected and subject to review by the editors and conference program committee. Some conference presentations may not be available for publication. The papers published in these proceedings reflect the work and thoughts of the authors and are published herein as submitted. The publisher is not responsible for the validity of the information or for any outcomes resulting from reliance thereon.

Please use the following format to cite material from this book:

Author(s), "Title of Paper," in Head- and Helmet-Mounted Displays XVI: Design and Applications, edited by Peter L. Marasco, Paul R. Havig, Proceedings of SPIE Vol. 8041 (SPIE, Bellingham, WA, 2011) Article CID Number.

ISSN 0277-786X

ISBN 9780819486158

Published by

SPIE

P.O. Box 10, Bellingham, Washington 98227-0010 USA

Telephone +1 3606763290 (Pacific Time) · Fax +1 3606471445

SPIE.org

Copyright (C) 2011, Society of Photo-Optical Instrumentation Engineers

Copying of material in this book for internal or personal use, or for the internal or personal use of specific clients, beyond the fair use provisions granted by the U.S. Copyright Law is authorized by SPIE subject to payment of copying fees. The Transactional Reporting Service base fee for this volume is $\$ 18.00$ per article (or portion thereof), which should be paid directly to the Copyright Clearance Center (CCC), 222 Rosewood Drive, Danvers, MA 01923. Payment may also be made electronically through CCC Online at copyright.com. Other copying for republication, resale, advertising or promotion, or any form of systematic or multiple reproduction of any material in this book is prohibited except with permission in writing from the publisher. The CCC fee code is $0277-786 \mathrm{X} / 11 / \$ 18.00$.

Printed in the United States of America.

Publication of record for individual papers is online in the SPIE Digital Library.

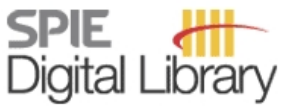

SPIEDigitalLibrary.org

Paper Numbering: Proceedings of SPIE follow an e-First publication model, with papers published first online and then in print and on CD-ROM. Papers are published as they are submitted and meet publication criteria. A unique, consistent, permanent citation identifier (CID) number is assigned to each article at the time of the first publication. Utilization of CIDs allows articles to be fully citable as soon as they are published online, and connects the same identifier to all online, print, and electronic versions of the publication. SPIE uses a six-digit CID article numbering system in which:

- The first four digits correspond to the SPIE volume number.

- The last two digits indicate publication order within the volume using a Base 36 numbering system employing both numerals and letters. These two-number sets start with $00,01,02,03,04$, $05,06,07,08,09,0 A, 0 B \ldots 0 Z$, followed by 10-1Z, 20-2Z, etc.

The CID number appears on each page of the manuscript. The complete citation is used on the first page, and an abbreviated version on subsequent pages. Numbers in the index correspond to the last two digits of the six-digit CID number. 


\section{Contents}

vii Conference Committee

\section{SESSION 1 HUMAN FACTORS ISSUES IN HMDS}

804102 Rise of the HMD: the need to review our human factors guidelines [8041-01]

E. E. Geiselman, P. R. Havig, Air Force Research Lab. (United States)

804103 Human-machine interface issues in the use of helmet-mounted displays in short conjugate simulators [8041-02]

J. E. Melzer, Rockwell Collins Optronics (United States)

804104 How much camera separation should be used for the capture and presentation of 3D stereoscopic imagery on binocular HMDs? [8041-03]

J. McIntire, E. Geiselman, E. Heft, P. Havig, Air Force Research Lab. (United States)

804105 Preliminary experimental results from a dichoptic vision system (DiVS) [8041-04]

M. P. Browne, SA Photonics (United States); K. Moffitt, Human Factors Consultant (United

States); D. G. Hopper, B. Fath, Air Force Research Lab. (United States)

804106 Evaluation of anti-glare applications for a tactical helmet-mounted display [8041-05]

J. L. Roll, Oak Ridge Associated Universities (United States); N. J. M. Trew, M. R. Geis,

P. R. Havig, Air Force Research Lab. (United States)

804107 Virtual reality in a cave: limitations and the need for HMDs? [8041-06]

P. Havig, J. McIntire, E. Geiselman, Air Force Research Lab. (United States)

\section{SESSION 2 HMD COMPONENTS}

804108 Sensor image augmentation to avoid saturation [8041-07]

K. Funabiki, H. Tsuda, Japan Aerospace Exploration Agency (Japan); K. Tawada, Shimadzu Corp. (Japan); T. Yoshida, NEC Corp. (Japan)

804109 Transfer alignment from a personal locator system to a handheld or head-mounted instrument [8041-08]

L. Ojeda, J. Borenstein, Univ. of Michigan (United States)

8041 OA Active matrix organic light-emitting diode (AMOLED) performance and life test results [8041-09]

D. A. Fellowes, M. V. Wood, A. R. Hastings, Jr., R. S. Draper, U.S. Army Night Vision \& Electronic Sensors Directorate (United States); A. Ghosh, O. Prache, I. Wacyk, T. Ali, I. Khayrullin, eMagin Corp. (United States) 
8041 OB Spatial noise in microdisplays for near-to-eye applications [8041-10]

A. R. Hastings, Jr., R. S. Draper, M. V. Wood, D. A. Fellowes, U.S. Army Night Vision \& Electronic

Sensors Directorate (United States)

\section{SESSION 3 CURRENT HMD DEVELOPMENTS}

8041 OC Binocular Scorpion helmet-mounted display [8041-11]

R. Atac, M. Edel, Gentex Corp. (United States)

8041 OD Wide field-of-view digital night vision head-mounted display [8041-12]

M. P. Browne, SA Photonics (United States)

8041 OE Full-color see-through daylight-readable goggle-mounted display [8041-13]

C. D. DeJong, MicroVision, Inc. (United States)

8041 OF Development of a dichoptic foveal/peripheral head-mounted display with partial binocular overlap [8041-14]

D. R. Tyczka, M. J. Chatten, J. B. Chatten, Chatten Associates, Inc. (United States);

J. O. Merritt, The Merrit Goup (United States); H. L. Task, Task Consulting (United States);

D. G. Hopper, B. A. Fath, Air Force Materiel Command (United States)

$80410 G$ Head-worn displays for NextGen [8041-15]

R. E. Bailey, K. J. Shelton, J. J. Arthur III, NASA Langley Research Ctr. (United States)

\section{SESSION 4 FLIGHT TESTS AND THEATER OPERATIONS}

$8041 \mathrm{OH} \quad$ Flight tests with enhanced/synthetic vision system for rescue helicopter [8041-16]

H. Tsuda, K. Funabiki, T. lijima, Japan Aerospace Exploration Agency (Japan); K. Tawada,

Shimadzu Corp. (Japan); T. Yoshida, NEC Corp. (Japan)

8041 Ol In-flight evaluation of an optical head motion tracker III [8041-17]

K. Tawada, M. Okamoto, Shimadzu Corp. (Japan)

8041 0J Qualification of the scorpion helmet cueing system [8041-18]

R. Atac, T. Bugno, Gentex Corp. (United States)

8041 OK The reported incidence of man-machine interface issues in Army aviators using the Aviator's Night Vision System (ANVIS) in a combat theatre [8041-19]

K. L. Hiatt, U.S. Army Research Institute of Environmental Medicine (United States); C. E. Rash, U.S. Army Aeromedical Research Lab. (United States) 
$8041 \mathrm{OL}$ Mask-mounted display (MMD) design considerations for diver operating environment [8041-20]

R. Manley, D. G. Gallagher, W. W. Hughes, C. G. Holmes, Naval Surface Warfare Ctr. (United States)

Author Index 
Downloaded From: https://www.spiedigitallibrary.org/conference-proceedings-of-spie on 26 Apr 2023

Terms of Use: https://www.spiedigitallibrary.org/terms-of-use 


\title{
Conference Committee
}

\author{
Symposium Chair \\ William Jeffrey, HRL Laboratories, LLC (United States) \\ Symposium Cochair
}

Kevin P. Meiners, Office of the Secretary of Defense (United States)

Conference Chairs

Peter L. Marasco, Air Force Research Laboratory (United States)

Paul R. Havig, Air Force Research Laboratory (United States)

Program Committee

Randall E. Bailey, NASA Langley Research Center (United States)

Sion A. Jennings, National Research Council Canada (Canada)

Session Chairs

1 Human Factors Issues in HMDs

Paul R. Havig, Air Force Research Laboratory (United States)

2 HMD Components

Peter L. Marasco, Air Force Research Laboratory (United States)

3 Current HMD Developments

Randall E. Bailey, NASA Langley Research Center (United States)

$4 \quad$ Flight Tests and Theater Operations

James M. Barnaba, Air Force Aeronautical Systems Center (United States)

5 HMDs in Non-Piloted Systems

Peter L. Marasco, Air Force Research Laboratory (United States) 
Downloaded From: https://www.spiedigitallibrary.org/conference-proceedings-of-spie on 26 Apr 2023

Terms of Use: https://www.spiedigitallibrary.org/terms-of-use 